\title{
Lost and Found Virginity: A Critical Look to the "Reappearing Hymen" in Consumer Culture
}

\author{
Yrd. Doç. Dr. Pelin AYTEMiz
}

başkent üniversitesi iletişim fakültesi radyo televizyon sinema bölümü paytemiz@baskent.edu.tr

\begin{abstract}
Although body modification is not a new phenomenon, hymenoplasty (the surgical restoration of the hymen), can be regarded as a new arena of struggle for the domination on the female body. Intact hymen as a sign of "purity" is a powerful phenomenon that gathers many cultural practices and reconstruction of it opens up novel discussions on the old established idea of virginity. This article focuses on how the presence of hymen as a proof of virginity, is commercialized and gains an exchange value via the domain of cosmetic/plastic surgery clinics and recently marketed non-surgical artificial hymen products. Advertisements of products that create the illusion of virginity and both the empowering and disempowering discourse around hymenoplasty are taken into consideration. Having in mind Jean Baudrillard's (1981) critique of usevalue, Stuart Hall's (1973) conceptualization of the polysemic nature of a sign and Michel de Certeau's (1994) ideas on everday life, advertisement texts and products are analyzed basing on the literature on consumer culture.
\end{abstract}

keywords: hymen, hymenoplasty, virginity, consumption culture 


\section{Resumé}

\section{Trouver la virginité perdue: Un regard critique à " I'hymen réapparaissant " dans la culture de consommation}

Même si les opérations esthétiques ne sont pas un phénomène nouveau afin de modifier le corps, I'hyménoplastie (l'opération chirurgicale de l'hymen) a évoqué un nouveau sujet de lutte contre la domination sur le corps des femmes. L'existence de l'hymen, en tant que le symbole de "pureté", apporte plusieurs pratiques culturelles et sa reconstruction débute des nouvelles discussions sur les pensées traditionnelles à propos de la virginité. Cet article est centré sur la commercialisation de l'hymen, considérée comme une preuve de virginité, par les opérations esthétiques et les produits artificiels de l'hymen. L'article traite surtout les publicités des produits supposés de créer une illusion d'hymen et insiste sur les discours ayant une dimension à la fois traditionnelle et tactique. La base théorique de l'article est la littérature critique sur la culture de consommation, enrichie par la critique apporté à la valeur d'usage par Jean Baudrillard (1981), par la conceptualisation de la nature polysémique du signe de Stuart Hall (1973) et par les idées de Michel de Certeau (1994) sur la vie quotidienne.

mots-clés : I'hymen, l'hyménoplastie, la virginité, la culture de consommation

\section{Özet}

\section{Kayıp Bekâreti Bulmak Üzerine: Tüketim Kültüründe Nükseden Kızlık Zarına Eleştirel Bir Bakış}

Beden görünümünün değiştirilmesi üzerine yapılan estetik operasyonlar yeni olmasa da, kızlık zarının restorasyon operasyonu (himenoplasti) kadın bedeni üzerine kurulan tahakküm konusunda yeni bir mücadele konusu yaratmıştır. "Saflığın" simgesiolarak kızlık zarının varlığı birçok kültürel uygulamayı beraberinde getirmekte ve rekonstrükyonu bekâret ile ilgili süregelen geleneksel düşünceler konusunda yeni tartışmalar başlatmaktadır. Bu makale, bekâretin kanıtı olarak kızlık zarının varlığının estetik operasyonlar ve pazarlanmaya başlanan yapay kızık zarı ürünleri ile nasıl metalaştııılığına ve alım satım değeri kazandığına odaklanmaktadır. Bekâret yanılgısı yaratan ürünlerin reklamlarına odaklanan yazı, himenoplastioperasyonlarının etrafında toplanan hem geleneksel hem de taktiksel bir yanı olması nedeniyle meydan okuyan söylemler üzerinde durmaktadır. Tüketim kültürü üzerine yazılan eleştirel kuramsal çerçeveyi kullanan yazı, Jean Baudrillard'ın (1981) kullanım değeri üzerine getirdiği eleştiriden, Stuart Hall'un (1973) göstergenin çokanlamlı doğasına dair kavramsallaştırmasından ve Michel de Certeau'nun (1994) gündelik hayat üzerine fikirlerinden yola çıkmaktadır.

anahtar kelimeler: kızlık zarı, himenoplasti, bekaret, tüketim kültürü 
Together with the technological and scientific developments in medicine, the body is becoming a unit to be altered, restored and modified. Body is becoming a canvas to be shaped and reshaped through the discourses of beauty along with the medical gaze.

In modern society, women face a bombardment of media images endorsing ideal feminine beauty. To achieve beauty, not only purchasing products and services are used, but also techniques of body modification via cosmetic surgeries are valued. Cosmetic surgery is increasingly becoming one of the popular consumerist acts of women who are using it to achieve cultural "myths" of beauty. Although body modification or transforming the physical body, is not a new phenomenon, hymenoplasty (the surgical restoration of the hymen), can be regarded as a new arena of struggle for the domination of the female body. Intact hymen as a sign of losing virginity and purity is a powerful cultural phenomenon that gathers many cultural practices, which embody power relations. Reconstruction of the hymen, in the domain of plastic surgery, is relatively a new area that opens up novel discussions on the old established idea of virginity. Hymenoplasty entails controversial questions in body reconstructions and in some cases could be regarded as an extreme example of provision of the body for someone else; that is to say; the dominant. Yet, artificial and fake hymen products that are marketed as a cheaper and easier alternative to surgeries takes the discussion to a more intricate and confusing state.

In this article, I would like to open up discussion focusing on how presence of hymen as a proof of virginity on websites is commoditized via the domain of recently marketed non-surgical artificial hymen products. How the discourse on artificial hymen products are articulated in online websites that market these products to Turkey. In what way the illusion of virginity is constructed through the non-surgical fake hymen products and to what kind of theoretical framework this discussion belongs to? How can one make sense of such cultural practices as a domain of negotiation in the discourse of virginity through the parts of the subordinate and the oppressive? These are some of the questions raised and discussed via content analysis in this research.

Search engines have great power on how people access information using the internet, as it recently became a generic knowledge retrievel platform. Highly ranked webpages have generally higher visibility and Google is one of the most popular search engines that have an algorithm that systematically ranks popular webpages (Su, Hu, Kuzmanovic and Koh 2010: 50-51). In order to trace various kinds of web sites that sell artificial virginity products online, Turkish and English generic keywords; "yapay kızlık zarı", "fake hymen kit", "artificial hymen products" and "virgin again" are used to access online stores. Relying on the ranking algorithm that google uses, the top web pages that are ranked higher in 
the result list are chosen ${ }^{1}$ as the source material to be analyzed. Although there are shops that are selling related products, online stores are preferred since the subject in question demands discretion. Online stores market their products

- either showing the artificial hymen products as the alternative for hymenoplasty: for instance http://www.artificial-hymen.info - accessed on 27.11.2015 - which offers free worldwide shipping writes "No surgery; No needles; No pre-surgical consultation; No gynecological examination; No pain; No medication; No side effects, No embarassment"

- or highlight the discreet shipping methods: for example http://www. yapaykizlikzarikani.com - accessed on 27.11.2015 - explains how confidential packaging system works as follows "your product will be delivered in closed cargo package without the inclusion of company name and content information. It will be delivered as DOCUMENT. You can receive your product with inner peace2"

Thus as a delibarete methodological choice instead of focusing publicity materails of stores, online webpages are included in the research as the primary source material.

The women who undergo hymenoplasty procedures, or use virginity related products, to whom they are having the procedure done and the way popular culture texts on reconstruction of virginity all play crucial roles in understanding the phenomenon. Alice Schlegel (1991: 719) in her article "Status, Property, and the Value on Virginity" writes "one way to assess a woman's autonomy is to ask whether she controls her own sexuality. Thus, the prohibition on premarital sex for females is often considered a measure of men's control over women's lives". In this sense, how can one make sense the act of the woman who undergoes hymenoplasty surgery or uses artificial hymen products? Is it done for the sake of "controlling her sex", or on the contrary, done out of cultural pressures such as fear on honorary killings? Can we regard the surgery as a "tactic", recalling Michel de Certeau's (1994) concept, that woman are using to overcome the suppressive domination of patriarchy that assigns some power to the woman to deceive dominating part? Alternatively, is it a kind of negotiation in the family for the sake of defending the family honor or is it a tricky practice that reinforces the

1 Some of the links that sells "virgin again products" and used as the source material of the research are as follows: bekaretzari.com, http://www.yapaykizlikzarikani.com/, http://bekarethapi. com/, http://hymenshop.com/?page=Home_Turkish, http://www.yapaykizlikzari.net/, http:// www.yaprakkozmetik.com/, http://www.artificial-hymen.info/, http://www.amazon.co.uk, http:// www.aliexpress.com/price/artificial-hymen_price.html, http://www.gigimo.com/, http://www. hymenshop.net/

2 The original text in Turkish writes: "Gizli Paketleme Nasıl? Alacağınız ürün kapalı kargo poşetinde, üzerinde firma adı ve içerik yazmadan EVRAK şeklinde size ulaşacaktır. Gönül rahatlığı ile teslim alabilirsiniz" 
patriarchal domination over the female body? In order to consider these issues, I will borrow Stuart Hall's (1973) conceptualization of the polysemic nature of a sign that he articulates in his famous article "Encoding and Decoding". For him, although the text prefers a certain dominant preferred reading/meaning, the readers may perceive the text differently and positioning themselves in three alternating modes that are (1) dominant/hegemonic position, (2) negotiated position and (3) oppositional position. A text could be read as a resistant one or as a text that perpetuates the preferred reading, or a subject could oscillate between those two positions. Using Hall's active model of the subject, I will try to figure out the different meanings that are gathered around the issue of virginity reconstruction techniques. As my object of research, I consider advertisements of products that create the illusion of virginity and the discourse on hymenoplasty. I will analyze the texts making use of the critical literature on consumer culture primarily borrowing Jean Baudrillard's (1981) articles that pose a critique of use-value, Stuart Hall's (1973) conceptualization of the polysemic nature of a sign and Michel de Certeau's (1994) ideas on everday life.

\section{Virginity as a Complex Symbol}

Hymenoplasty procedure and other non-surgical artificial hymen products are ways by which some women reinstate the appearance of virginity. Within a culturally embodied structure of dominant and docile groups, this phenomenon is created as a controversial practice that uses hymenoplasty and such related surgeries to negotiate deceive or defeat oppressive groups. Motivations and justifications of such a cosmetic procedure are debatable and complex to any culture that values the appearance of virginity as a societal or religious enforcement. Within such cultural spheres, hymen that symbolizes virginity has become a commodity.

There are many ways to approach what virginity is about, and what does it mean to be a virgin. With the destruction of the hymen, what is lost is a multiended question. Laura M. Carpenter (2002) in her article called "Gender and the Meaning and Experience of Virginity Loss in the Contemporary United States"3 argues; "virginity loss is widely understood (...) as a central event in the process through which girls and boys become adult women and men." 4 She regards virginity loss as a "social and sexual transition, a rite of passage constituting part of the irreversible journey from childhood to adult life" (2002: 5). Whereas; for Clarissa W. Atkinson (qt. in Driver, 2004), there are two kinds of approaches to the issue of virginity: some see virginity "as a physiological state" and the virgin as being someone "who has never had sexual intercourse"; conversely,

3 The article is about how young people in the United States assign different meanings to virginity and experience virginity loss based on their gender.

4 In this paper, as my primary concern is the meanings clustered around the "hymen", I will be focusing on the idea of virginity loss that is related to female body and will deliberately neglect the virginity loss in male gender. 
there are those who regard "virginity as a moral or spiritual state - as purity or humility". In this sense, regarding the above projections on virginity, the concept oscillates between two categories that are linked together. One is the physical body, and the other is the social performance. There is a desire to capture the abstract notion of "purity" that is assigned to the hymen as a symbol of virginity.

In many Muslim cultures, virginity is calculated with the presence of the hymen. The hymen is a representation of honor that the woman is responsible for "defending". Suzanne Ruggi in her 1998 article called "Commodifying Honor in Female Sexuality: Honor Killings in Palestine" writes that "family status is largely dependent upon its honor, much of which is determined by the respectability of its daughters, which can damage it irreparably by the perceived misuse of their sexuality." In this sense, hymen is a potent symbol that has various meanings in different context. By losing the hymen that is to say the virginity; sometimes the honor of the family is considered as destructed, sometimes it is considered to be the ending of the childhood period - like a step to adulthood - or as symbol of a missing purity. Here, each interpretation of virginity somehow creates distinct patterns of gender subordination. The discourses on virginity consistently gave men power over women.

\section{Artificial Virginity Products: Power Struggles on Female Body}

I am curious about how can one make sense of a desire to capture an illusion of virginity through the artificial reproduction of the hymen. Because in consumer culture societies even virginity is turned out to be a commodity that those who lost it can now ironically pay and get it back easily. For example one online site writes that virginity can simply be recovered in the blink of an eye in these words: "In 15 minutes get your virginity back and be freed from despair" (http://www.yapaykizlikzarikani.com, accessed on 27.11.2015) 5. Via the artificial hymen, the restored hymen by the surgical operation, or the natural hymen of a woman is believed to have; the idea of virginity is being sold. In each case, in the construction of virginity as a phenomenon, there is a regime of exchange. No matter for what purpose the virginity idea is used (to deceive the partner, to overcome patriarchal forces or to present the female body as a gift etc.) there is a kind of ideological production of an abstract concept and consumption of it.

Jean Baudrillard (1981) in his article called "The Ideological Genesis of Needs" discusses that to find the meaning of consumption one should look at the latent meaning. For him, the naturalized assumption that subjects need objects is a tautological explanation that tries to make sense of the consumption. For him, the need does not exist at all. It is an ideological concept to justify the system of exchange. The system of needs is a product of capitalist societies.

5 The original Turkish text writes: "15 Dakikada Bekaretinize Kavuşun. Umutsuzluktan Kurtulun" 
About the illusion of needs, in such alienated societies it seems that the only way for subjects to relate with objects is choosing, that is offered as a free activity. Choice is given as a free activity and creates a kind of illusion that naturalizes the logic of need. Using this framework, Christina M. Touarti tries to understand plastic surgery in her 2007 thesis named Representation of Cosmetic Surgery in Women's Magazines. She writes that

"Women often perceive the process of cosmetic surgery as an individual choice unaffected by cultural ideals, giving the feeling of control and autonomy. This sense of individualism occurs because the process of diagnosis begins with the women."

When analyzing medical texts discussing cosmetic surgery Touarti continues observing and writes:

"Through the process of self-diagnosis and research, women get an increased feeling of choice and responsibility. The sense of individualism gained through the process allows them to perceive their decision to be unaffected by the influence of cultural norms."

In this context, the issue of artificial virginity and reconstruction procedures cannot be taken into consideration without the discussion of need and choice. Similar to any kind of plastic surgical operation, hymenoplasty is also a product of beauty industry that encourages women to use mass produced products and surgery techniques to express their individuality by the illusion of choice as a free activity.

What is being offered and advertised by hymenoplasty operation and the non-surgical products that are on sale is the promise of virginity, beauty and uniqueness it connotates. The illusion of virginity that these products and surgical operations are offering can be read as another way to show how extreme ways the capitalist society is obsessed with controlling women's body and sexuality. This is an outcome of the patriarchal psyche that offers a fetishistic idealization of virginity as something sacred and a kind of commoditization of female body. The problematic part is how the myth of perfection and beauty is naturalizing the ideology and presenting such operations as a free choice or need to the woman. Woman body is again being commoditized as something to be consumed by the male pleasure, desire, and power.

Virginity is a complex issue that entails many narrations and rituals; should be regarded in context based. The motivation and the reason that a woman is using the artificial hymen products or going under a surgical operation should be taken into consideration. In some cases, even the illusion of choice is also not the issue. Situations in which choosing to have a surgery with the motivation of fear, should be regarded as a powerful force of patriarchy. Suzanne Ruggi in her 
1998 article called "Commodifying Honor in Female Sexuality: Honor Killings in Palestine" writes that

"For a woman, virginity is the property of the men around her, first her father, later a gift for her husband; a virtual dowry as she graduates to marriage. In this context, a woman's 'ard (honor) is a commodity that must be guarded by a network of family and community members. The woman is guarded externally by her behavior and dress code and internally by keeping her hymen intact."

If the aim in choosing to use the products and undergo surgery is to avoid harsh consequences of patriarchy such as to avoid disapproval or even death, this should be read as an act reinforcing the empowerment of woman. In such cases, one cannot talk about any choice but only a submission to authority. On the contrary, in some cases, virginity is aligned with gift giving which presuppose someone to receive the gift. For one of the respondent in Carpenter's research (2002), who regard chastity as a kind of gift giving describes virginity loss as these words: "that you are willing to give up something private of yourself ... (It is) something of mine that I choose to give up, that I can only give up once." Carpenter comments on this saying that "this group saw virginity as a highly valuable gift, due to its nonrenewable nature and their sense that it was part of the self that would be forfeited on". Such a conceptualization of virginity loss as a gift can be understood in the domain of Symbolic Exchange Baudrillard (1981) defines. For him there are four different kinds of networks that objects are in relation with, which are; Exchange Value Regime, Use Value Regime, Logic of Symbolic Exchange and Logic of Sign Value. I regard the reconstruction procedures and products that sell the idea of virginity as a kind of ambiguous object that communicates through the regime of the Symbolic Exchange. The value of the gift; virginity is meaningful only in that particular context and has value determined by the social relation it entails. The protected hymen as the object of the gift (symbolizing purity and the commitment of the woman to her husband) is actually not seen at all but only manifested and materialized by the blood drops. The sheet and the blood of the virgin is a powerful symbolic material that is kept and acts as a unique object of commitment between the couple that is symbolizing marriage and proof of virginity. What is important here is not the materiality of the hymen or the blood on the sheet but the symbolic value it entails.

The surgery and artificial hymen product advertisings can also be decoded within the negotiated decoding mode that Stuart Hall (1973) describes. This method of decoding contains a mixture of adaptive and oppositional elements. Such a positioning acknowledges the legitimacy of the hegemonic definition but at the same time inflicts it locally to take account of one's social position. It is obvious that such surgeries and products are not appropriated via the patriarchy as it serves to deceive the father-husband figure and is working on hiding a so- 
called $\sin ^{6}$. As an example of a negotiated reading of such procedure, I would like to quote a patient who explains why she had the hymenoplasty surgery that appeared in a woman's magazine. Ceyda, 24 years old, stated that;

\begin{abstract}
"I am marrying into a modern family... I am sure that [my fiancé] would stay with me if he knew I was not a virgin...But my mother says...men will value you more if they think they are the only ones who have had you. A fresh product is better than a spoiled one. So why not? My husband should value me, and I do not mind doing something this easy to make him happy; it takes only half an hour." (Available at: http://thefbomb.org/2009/10/artificial-virginity, accessed on 29.12.2009)
\end{abstract}

Ceyda thinks of herself as a "spoiled product" for having had sex. The reason for her to have an operation is to make her "fresh" for her husband to be. I regard this reasoning as a perpetuating act of patriarchal psyche but still find it including a subversive meaning that entails a way that tricks the power. One can see a negotiation among the family members (mother-daughter) via a negotiated reading of hymenoplasty. The myth of purity via the presence of hymen is reproduced for the sake of defending the honor of the family but only by a fake innocence. The myth of virginity is so much naturalized that even the illusion of virginity with the hymenoplasty is enough for subjects to align themselves to the patriarchal psyche. Such woman is naturalizing the myth in such a way that they do not find any problem spending thousands of dollars to have their virginity restored, although it by default includes an act of modification. At the same time to use surgery as a weapon in power struggles could be regarded as a positioning that is oscillating between the dominant reading and oppositional code that Stuart Hall (1973) is defining.

In both cases, similar to the myth of beauty that plastic surgery recalls, in such an attitude women observes their own body through someone else's eyes to satisfy the will of the dominant. Such internalization of the patriarchal psyche is perpetuating the disempowerment of woman at virginity loss.

\title{
Artificial Virginity Products: A Subversive Reading
}

\section{"Virgin Again - It's Your First Time Again}

Too many lovers, too little time to erase them from your memory? Not anymore. Take these and you will become a born-again virgin. Virginity in a pill! It is the answer you've been looking for. Take as often as needed. There is no limit to how many times you can be born-again".

6 One can give the reaction that came from Egypt as an example. Artificial hymen products are being regarded as a threat and tried to be banned. The News article writes that "Conservative Egyptian lawmakers have called for a ban on imports of a Chinese-made kit meant to help women fake their virginity and one scholar has even called for the 'exile' of anyone who imports or uses it." Available at: http://www.cbsnews.com/stories/2009/10/05/ap/middleeast/main5364099.sht $\mathrm{ml}$, accessed on 7.1.2010 
Figure 1: "Virgin Again Pills" 7

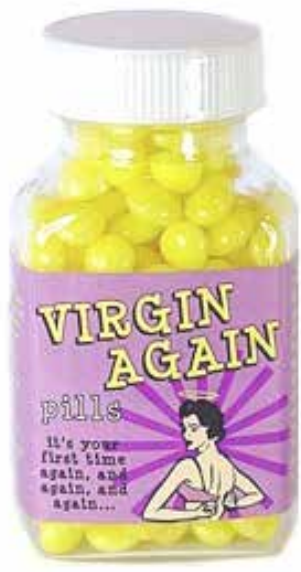

Hymen as a physical female body part, although is not something that is visible (apart from medical gaze) is being commoditized via various ways. Although it is vaguely defined and out of the domain of the vision, is repeatedly produced and sold as a meta. By this interesting invisible hard to identify body piece, honor, purity and childhood is objectified and in a fetishistic way reconstructed by the products and surgeries. Through the commoditization and reification of the hymen, in some contexts, the power struggle that is being played using the female body is questioned. In this sense, can one read the "illusion of virginity" provided by artificial hymen reconstruction surgeries and relate products in the domain of oppositional code that Stuart Hall (1973) defines?

Roland Barthes' famous book Mythologies published in 1957 is a collection of essays examining social value systems that creates what he calls Myth. Myth is "a type of speech" (Barthes 1957) that is formed to perpetuate the society that holds on the current ideologies of the ruling class. The socially constructed, notions, codes, and narratives become naturalized and taken for granted in the functioning of myths. In this sense, one can talk about a myth of virginity that is forcing female body and sex to be under the domination of patriarchy. For Barthes it is difficult as myths do not hide anything, it distorts and "transforms history into nature". It proposes as if the subject matter is eternal, not to be questioned by naturalizing the myth. In this sense, all the efforts of woman to defend their honor and avoid pre-marital sex, perceiving their virginity as precious and strove to maintain it until they were married, or the idea of virginity as a gift to the husband is reinforcing the myth of virginity. The reflection of this idea can be seen in the slogan used to advertise a fake hymen product; " the awaited miracle

7 Avaliable at: http://store.offbeattreats.com/VIRGINAGAINPILL.html. 
took place"8 (http://www.yaprakkozmetik.com, accessed on 27.11.2015). Now miraculously the myth of virginity is accessible. When needed, one can buy it.

However what happens when virginity is commoditized and when it can be artificially reproduced? For Barthes, the best weapon to counter a myth is to mythify it in its turn; that means to create an artificial myth. In this sense, I ask; can one say that the illusion of virginity that is created via the plastic surgeries or by the existing of artificial hymen products opens up a way to a false myth, which presents a way of mythizing the myth of perfect virgin female body? In this sense, I think it can be a way to subvert the cultural hierarchies of the existing virginity discourse. Here one can say that the artificial hymen is destructing the sanctified and valorized connotation of virginity. Through producing its false copy and advertising it in the name of Virgin Again (please see the product and advertisement in Figure 1) one can see a challenging view regarding virginity. The name of the product "Virgin Again" and its tagline "It's Your First Time Again" promises the user to undo or to erase a past activity: the loss of virginity. It promises the buyer something impossible: to experience something again as if it is the first time experience. Virginity that is valued and obsessed via patriarchy to such extent that it may result in murder, is presented in such a simple and ironic way (take the pill and you are virgin again). Here one might find a deconstructive power that challenges the abstract holistic notion that is attached to virginity in a satiric way. I consider the presence of these pills as presenting and displaying the absurdity of virginity and the high and dense associations and connotations (as the family honor) it carries.

Figure 2: A t-shirt sold online for $\$ 19.95^{9}$

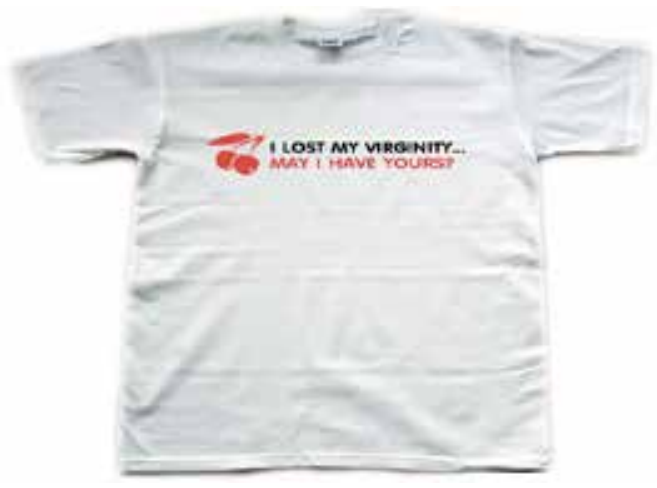

8 The original Turkish text writes: "Beklenen mucize gerçekleşti".

9 Available at http://www.zazzle.com/i_lost_my_virginity_can_i_have_yours_2_tshirt-2351895131 65081255 . 
Figure 3 A t-shirt sold online for $\$ 30.7010$

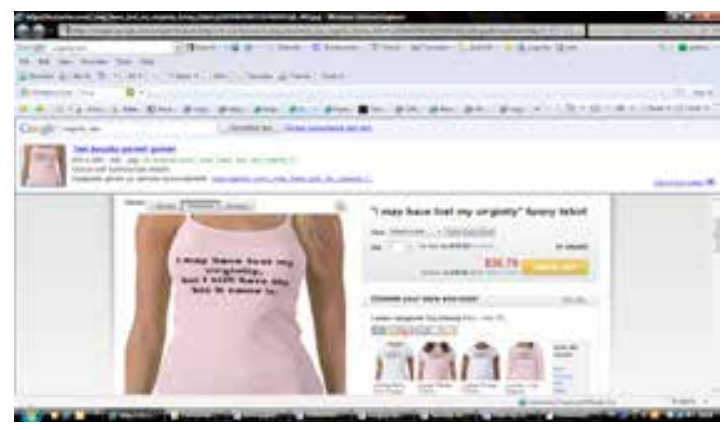

Briefly, in popular culture, virginity is objectified to such an extent that now it can be lost and found again. Such an interpretation of virginity, apart from its sacred connotations is presenting an ironic and subversive reading.

In this sense, taglines that are printed on t-shirts such as "I lost my virginity, may I have yours" in Figure 2 can be an example of the commoditization attitude found in popular culture texts and be read as challenging practices. This tagline regards virginity as if a commodity in a satirical way that recalls an "exchange". In another t-shirt (see Figure 3) it writes "I may lost most my virginity, but I still have the box it came in". In this example, the satire comes from the idea that virginity is regarded as a product in such an extreme way that it even comes with a package/box.

Figure 4. Artificial Hymen Kit sold by the company Gigomo via the tagline "Let's Play" 11
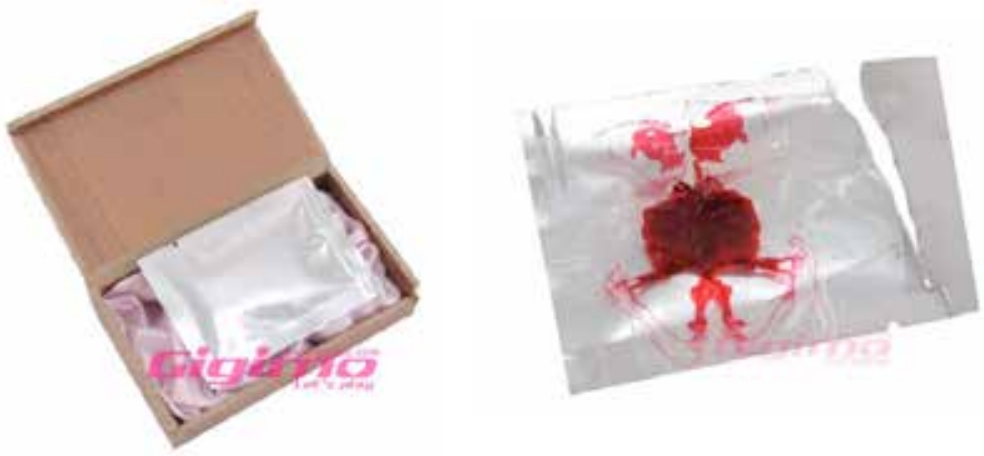

10 Available at http://www.zazzle.com/i_may_have_lost_my_virginity_funny_tshirt-2359402992315 76859.

11 Available at: http://www.gigimo.com/main/product. 
Artificial Virginity Hymen $\mathrm{Kit}^{12}$ (see in Figure 4) that is distributed by a Chinese company called Gigimo is sold for an exchange value ${ }^{13}$ The product is using the familiar symbol of blood in the sheets as its use-value ${ }^{14}$ (http:// www.yaprakkozmetik.com, accessed on 27.11.2015). This product promises women to pass the "virginity test" the patriarchy is forcing. It plays with the rituals of the "first night": where the woman is supposed to accomplish and prove their chastity. Not only the sense of tightness of the hymen is imitated, but also the whole performance of losing virginity is re-narrated and defined in this advertisement. One website comments on the mystical first night and regards it as a threshold of being loyal. For them, "what is important is your loyalty after the marriage"15 (http://bekarethapi.com/, accessed on 27.11.2015). One can say that from the visual proof of blood to the performance of the woman, the mythical first night is reinterpreted and presented to woman to act accordingly. Although what this product suggests is in the domain of the patriarchal psyche and somehow reinforces the rituals of losing virginity, by assigning the knowledge to the woman and via creating a space to perform virginity loss is actually breaking the rules of the game of the dominant ideology.

As a concluding remark, one can say that the artificiality of the hymen, the fake blood, the performance of the woman makes the first-night illusion like a parody that deconstructs the natural emphasize of the myth ${ }^{16}$. The artificial hymen products also deconstruct the whole artificiality of the ideology on virginity ritual. Hymenoplasty procedure and the products providing artificial hymen has a discursive function in modern societies that are both empowering and disempowering to the woman who is having the operation done or having used the artificial hymen products.

12 The same product and similar one are being sold online shopping stores such as gittigidiyor. com or specialized web sites devoted to this product such as http://www.yapaykizlikzari.com/ anasayfa.html in Turkey under the name of "Yapay kızlık zarı" with a tagline of "Bekaretinizi kaybettiniz diye üzülmeyin!"

13 A similar product Virgiseal is sold for $290 \$$. In its advertisement, it compares the product with the surgical operations and the cheaper relative products. The tagline is "Practically proven, Non-Asurgical solution for hymen restoration (re-virgination) (http://www.virgiseal.com/.) On the Turkish market the product price varies from $150 \mathrm{TL}$ (marketed on http://www.yapaykizlikzarikani. com/) to $199 \mathrm{TL}$ (marketed on http://bekarethapi.com)

14 The original Turkish text writes: "Etkisi, kadın acı çekiyormuş gibi yaparsa ve utangaç davranırsa daha da artacaktır."

15 The original Turkish text writes: "Önemli olan evlilik sonrası sadakatinizdir."

16 One should also note the study of Carpenters on virginity (2002). She focuses on how the meaning of "virginity loss" differs by gender. What is interesting in Carpenter's article is that she looks at both heterosexual and homosexual relationships and their sexual encounters and researches on what virginity means for young gay men and lesbians. Such an approach can be regarded as a deconstruction of virginity myth that is operating in the domain of patriarchal psyche and actually using female body as its domination area. When the issue of virginity is extended to the body of the gay or the lesbian, the discussion turns out to be a more complex and subverting one. Similar to virgin again virginity pills, the story or abstract image of a lesbian girl first sexual experience with another girl in the domain of virginity loss is challenging the whole patriarchal myth of virginity. 
Figure 5: The product description of Artificial Virginity Hymen Kit ${ }^{17}$

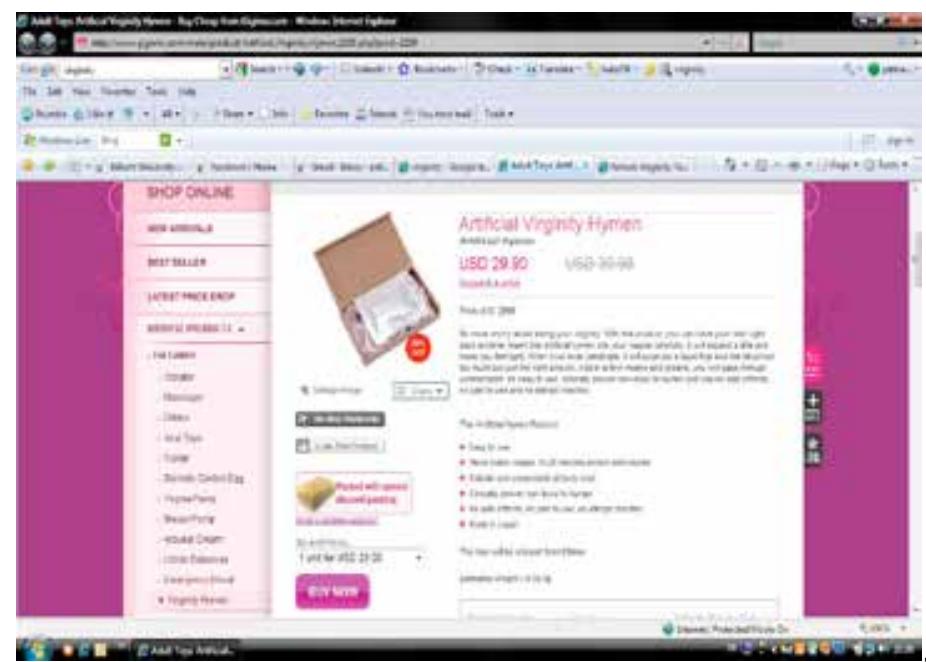

\section{References}

BAUDRILLARD Jean (1981), "The Ideological Genesis of Needs", For a Critique of the Political Economy of the Sign, Telos Press Publishing.

BARTHES Roland (1957), Mythologies, Trans, Annette Lavers, New York The Noonday Press.

CARPENTER Laura (2002), "Gender and the Meaning and Experience of Virginity Loss in the Contemporary the United States", Gender and Society, Vol. 16, No. 3, Sage Publications pp. 345-365.

DE CERTEAU Michel (1994), The Practice of Everyday Life, Trans. Steven Rendall, Berkeley, University of California Press.

DRIVER Martha (2004), Sid Ray in The Medieval Hero on Screen: Representations from Beowulf to Buffy, McFarland \& Company.

HALL Stuart (1973), “Encoding Decoding" Culture, Media, Language: Working Papers in Cultural Studies, London, Hutchinson, pp. 128-138.

RUGGI Suzanne (1998), "Commodifying Honor in Female Sexuality: Honor Killings in Palestine" Middle East Report: Power and Sexuality in the Middle East, No. 206, pp. 12-15, Middle East Research and Information Project.

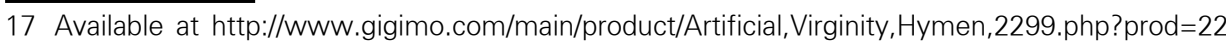
99. 
SCHLEGEL Alice (1991), "Status, Property, and the Value on Virginity" American Ethnologist, Vol. 18, No. 4, Blackwell Publishing, pp. 719-734.

SU Ao-Jan, HU Charlie, KUZMANOVIC Aleksandar, KOH Ceng-Kok (2010), "How to Improve Your Google Ranking: Myths and Reality" Web Intelligence and Intelligent Agent Technology (WI-IAT), 2010 IEEE/WIC/ACM International Conference, Vol.1, pp. 50-57.

TOUARTI Christina (2007), Representation of Cosmetic Surgery in Women's Magazines, Thesis submitted to Kent State University. 